\title{
PROFILE OF PATIENTS SEEN AT AN OUTPATIENT HYPERTENSION FACILITY: ARE THERE GENDER DIFFERENCES?
}

\author{
Anelise Sampaio CAVALHEIRO ${ }^{\text {a }}$, Mariana Jaeger FONSECA ${ }^{\text {, }}$ \\ Graciele SBRUZZI' ${ }^{c}$, Silvia GOLDMEIER ${ }^{\mathrm{d}}$
}

\begin{abstract}
The objective of this study was to find out whether there are gender differences regarding socio-demographic characteristics and associated risk factors in adults monitored in an outpatient hypertension facility. Retrospective analysis of records of patients seen at the outpatient hypertension clinic in 2009-2010, in a hospital specialized in cardiology, in southern Brazil. All patients were beneficiaries from the Brazilian Unified Healthcare System (SUS). The variables considered were socio-demographic profile, anthropometric measurements and risk factors for hypertension. For statistical analysis, a significance level of $5 \%(\mathrm{p} \leq 0.05)$ was adopted. Of the 209 patient records assessed, most belonged to female patients (66\%), $65.9 \%$ of them were married, $71.6 \%$ were white, with mean age $53.5 \pm 13.8$ years, and $70.1 \%$ had a sedentary behavior. Regarding risk factors, waist circumference and alcohol use were higher among men $(\mathrm{p}=0.04)$. It was concluded that there was no gender difference concerning the assessed variables, except for the use of alcohol.
\end{abstract}

Descriptors: Hypertension. Risk factors. Gender and health.

\section{RESUMO}

Objetivou-se identificar, em adultos acompanhados no ambulatório especializado em hipertensão arterial sistêmica, se há diferença entre sexos quanto às características sociodemográficas e fatores de risco associados. Estudo retrospectivo de análise de prontuários de pacientes atendidos no ambulatório de hipertensão no período 2009-2010, em um hospital especializado em cardiologia, na região sul do Brasil. Todos os pacientes eram oriundos do Sistema Único de Saúde. Considerados como variáveis o perfil sociodemográfico, as medidas antropométricas e os fatores de risco para hipertensão. Para análise estatística, adotou-se o nível de significância de 5\% ( $p \leq 0,05)$. Evidenciou-se que, dos 209 prontuários avaliados, predominou sexo feminino (66\%), casados (65,9\%), brancos (71,6\%) e sedentários (70,1\%), com idade média de 53,5 \pm 13,8 anos. Dos fatores de risco, a circunferência abdominal e o consumo de álcool foram maiores entre os homens $(p=0,04)$. Concluiu-se não existir diferença entre os sexos quanto às variáveis analisadas, exceto quanto ao uso de álcool.

Descritores: Hipertensão. Fatores de risco. Gênero e saúde.

Título: Perfil de pacientes atendidos em um ambulatório de hipertensão arterial: há diferenças entre sexos?

\section{RESUMEN}

Se objetivó identificar en adultos acompañados en ambulatorio especializado para la hipertensión, si hay diferencias entre los sexos, características sociodemográficas y factores de riesgo para hipertensión. Estudio retrospectivo de registros de pacientes tratados entre 2009-2010 en ambulatorio de hipertensión, de un hospital especializado en cardiología, en el sur de Brasil. Todos los pacientes eran del Sistema Nacional de Salud. Se consideró como variables el perfil sociodemográfico, las mediciones antropométricas y los factores de riesgo para la hipertensión. Para el análisis estadístico adoptó el nivel de significancia del $5 \%(p \leq 0,05)$. Evaluó a 209 pacientes, mujeres(66\%), casados(65,9\%), blanco(71,6\%), sedentario(70,1\%) y edad 53,5 $\pm 13,8$ años. Los factores de riesgo como la circunferencia abdominal y el consumo de alcohol fue mayor entre los hombres $(p=0,04)$. Concluyó que no había diferencia entre géneros con respecto a las variables, excepto para el uso de alcohol.

Descriptores: Hipertensión. Factores de riesgo. Género y salud.

Título: Perfil de los pacientes atendidos en clínica de hipertensión arterial: ¿̨ay diferencia entre géneros?

\footnotetext{
a Nurse. Postgraduate student of Nursing in Cardiology at Instituto de Cardiologia/Fundação Universitária de Cardiologia (IC/FUC). Clinical Nurse of Hospital Pavilhão Pereira Filho. Porto Alegre, RS, Brazil.

b Nurse. Postgraduate student of Nursing in Cardiology of IC/FUC. Porto Alegre, RS, Brazil.

c Physiotherapist. PhD in Health Sciences: Cardiology at IC/FUC. Professor of Physiotherapy at Universidade Federal do Rio Grande do Sul (UFRGS). Porto Alegre, RS, Brazil.

d Nurse. PHD in Health Sciences: Cardiology at IC/FUC. Professor of the Lato-sensu Postgraduate course Nursing in Cardiology of IC/FUC. Porto Alegre, RS, Brazil.
} 


\section{INTRODUCTION}

Systemic arterial hypertension (SAH) is characterized by high and sustained levels of blood pressure (BP), being a multifactor disease that includes the following risk factors: excessive salt intake and alcohol use, obesity, sedentary behavior, smoking, dyslipidemia, diabetes mellitus, among others $^{(1)}$.

The functional changes caused by the SAH in organs such as heart, brain, kidneys and blood vessels ${ }^{(1-2)}$ increase the risk of fatal and non-fatal cardiovascular events. In Brazil, cardiovascular diseases (CVD) are the leading cause of death. In 2007 there were 308.466 deaths from cardiovascular diseases, representing $29.4 \%$ of all other causes of death ${ }^{(3)}$. Since SAH is one of the main causes of CVD, patient adherence to treatment is essential. The challenges to treatment include the adoption of healthy lifestyles and coping with the factors that make it difficult for the individuals to observe the recommendations of health professionals. Non-adherence to pharmacological treatment has been reported as the main obstacle to the effectiveness of these recommendations ${ }^{(4)}$.

The Brazilian Society of Cardiology issued in 2010 the VI Brazilian Guidelines on SAH, highlighting the following risk factors for hypertension: age, sex and ethnicity, overweight and obesity, socioeconomic factors, salt intake and alcohol, sedentary lifestyle and genetics ${ }^{(1)}$. Besides these, environmental factors tend to reinforce this combination in families with an unhealthy lifestyle. Psychosocial factors such as chronic stress, socioeconomic status, personality, depression and social support are related to high blood pressure ${ }^{(1)}$.

Population-based surveys demonstrated the prevalence of SAH between 1990 and 2004, from $22.3 \%$ to $43.9 \%$ in some Brazilian locations. .About $80 \%$ of the patients can be treated in the primary healthcare structure, indicating the need for the development of the multidisciplinary team responsible for family health programs. Systemic arterial hypertension (SAH) or high blood pressure (HBP) is among the most frequent chronic disorders, accounting for $40 \%$ of deaths from stroke (CVA) and $25 \%$ of those from coronary heart disease ${ }^{(5-6)}$.

Concerned with the high death rate, the Ministry of Health implemented in 2006 a population-based survey, the Vigitel - Vigilância de Fatores de Risco e Proteção para Doenças Crônicas por Inquérito Telefônico (Surveillance of Risk and Protective Factors for Chronic Diseases by Telephone Interviews). Updated annually, this survey publishes the frequency and distribution of the main indicators of non-communicable diseases (DCNT) in Brazil. According to the first result, published in 2007 the DCNT were responsible for $72 \%$ of total deaths, especially diseases of the circulatory system (31.3\% of the deaths). Among the risk factors, regardless of gender, overweight, obesity and physical inactivity increased considerably in the last 5 years ${ }^{(7)}$.

A cross-sectional study conducted in Germany with 2,482 patients, in primary healthcare centers for hypertensive patients showed that the sample remained distributed evenly by gender $(51 \%$ of women) and that, of the entire sample, only $29.1 \%$ of the patients had controlled $\mathrm{BP}{ }^{(8)}$.

Young women tend to have lower BP and lower risk of hypertension compared to young men. As people age, BP and the risk of hypertension increase in both sexes. In women, these rates occur, in most cases, after the menopause. Hormone replacement therapy (HRT) and selective modulators of estrogen receptor should not be used for primary and secondary prevention of CVD. In cases of younger perimenopausal women, with severe symptoms, the benefits of treatment should be weighed against the potential risks of HRT. The probability that there is further increase in $\mathrm{BP}$ in hypertensive women after menopause is low ${ }^{(9)}$.

Thus, the present study aimed to find out whether there are gender differences regarding socio-demographic characteristics and risk factors for SAH in adults monitored in an outpatient facility specialized in SAH.

\section{MATERIALS AND METHODS}

This is a retrospective, descriptive study of a review of patient records, originated from a randomized clinical trial with hypertensive patients seen in a hypertension outpatient facility of a cardiology referral center of Rio Grande do Sul, Brazil, in 2009-2010. The outpatient facility, known as MULTIHAS, is meant for adult hypertensive patients of the Brazilian Unified Healthcare System (SUS). The treatment of hypertensive patients is made by a multidisciplinary team composed of 
nurse, psychologist, physiotherapist, nutritionist and doctor.

This study included records from patients older than 18 years with primary SAH selected by the staff responsible for screening of the outpatient facility. The exclusion criteria were: patients with secondary hypertension, severe hypertension difficult to control, rebound hypertension, surgical patients with congenital disease.

The review of patient records was performed in July 2010, totaling 209 records. The survey instrument used was a structured questionnaire with data on the sociodemographic profile, lifestyle, presence of SAH and associated risk factors. The risk factors for SAH considered in this study were: smoking (up to one cigarette per day); sedentary lifestyle (no physical activity or performed for less than 30 minutes/day five times a week); obesity (body mass index (BMI) greater than or equal to $\left.29.9 \mathrm{~kg} / \mathrm{m}^{2}\right)$; alcohol abuse (up to $30 \mathrm{~g}$ ethanol $\mathrm{g}$ /day); fasting glucose equal to or greater than 100 and total fasting cholesterol greater than $200 \mathrm{mg} / \mathrm{d}^{(10)}$.

Waist circumference, weight and height were obtained from records. The measurements performed by the staff were based on the VI Diretriz Brasileira de HAS (VI Brazilian Guideline on Hypertension), which assesses visceral obesity taking the values of $88 \mathrm{~cm}$ for women and $102 \mathrm{~cm}$ for men, as a standardized target. The weight and height were used to calculate BMI, and obesity was defined as BMI greater than or equal to $29.9 \mathrm{~kg} / \mathrm{m}^{2(1)}$.

The patients were evaluated at the first visit, and $\mathrm{BP}$ and $\mathrm{BMI}$ were measured as recommended by the Guidelines ${ }^{(1)}$. For the BP, the average of the values obtained in the first appointment was considered. Similarly, the patients, in the fasting state, were referred for biochemical testing after consultation with the physician.

The categorical variables were expressed as percentage or absolute value; the continuous variables with normal distribution were expressed as mean \pm standard deviation with asymmetric distribution, as median and percentiles $25 \%$ and $75 \%$. "T" student test was used for comparison between groups and chi-square test was used for the qualitative variables. The Pearson Correlation Coefficient was used to assess the correlation between variables. $p \leq 0.05$ was considered significant. The data were entered into an Excel spreadsheet (version 18 of SPSS for Windows).
This research was conducted in accordance with the ethical standards required under Resolution 196/96 ${ }^{(11)}$. The project was approved by the Ethics Committee in Research of Instituto de Cardiologia do Rio Grande do Sul under number 3927/06. The researchers signed a Commitment to research patient records.

\section{RESULTS}

Records of 209 patients were evaluated. The sample consisted predominantly of women (66\%) with mean age $54.3 \pm 13.5$ years. The patients were predominantly married, white and had completed the early years of elementary school. (Table 1).

Table 2 shows the prevalence of risk factors for $\mathrm{SAH}$ between the sexes. The prevalence was similar in all variables, except for alcohol use, which predominated among men ( $\mathrm{p}=0.04)$; waist circumference was increased in both sexes, with statistical significance in males $(p=0.04)$.

\section{DISCUSSION}

The results of this study showed that most patients were white women with complete elementary education, who had a partner. It was also observed that, among the studied risk factors for $\mathrm{SAH}$, alcohol use was the only risk factor that differed between genders, present among men. The other risk factors did not diverge between genders.

Regarding the predominance of females in the sample, the data are consistent with one study carried out in the Basic Healthcare Unit of Londrina, PR, Brazil, with a hypertensive population, where most of the sample (62.4\%) was also composed of women. This indicates the greater awareness of women regarding their healthcare and greater adherence to treatment compared to men $^{(12)}$. The low demand for healthcare services by men is due to two groups of determining factors that are structured as barriers between men and healthcare services: sociocultural and institutional barriers ${ }^{(13)}$.

Accordingly, another cross-sectional study in an outpatient hypertension facility showed a striking predominance of women, accounting for more than $70 \%$ of the patients studied. Regardless of whether they were in their first appointment or not, women used antihypertensive drugs 
Table 1 - Sociodemographic characteristics of the sample $(\mathrm{n}=209)$. Porto Alegre - RS, 2009-2010.

\begin{tabular}{lccc}
\hline \multicolumn{1}{c}{ Variables } & $\begin{array}{c}\text { Female gender } \\
\mathbf{n}(\%)\end{array}$ & $\begin{array}{c}\text { Male gender } \\
\mathbf{n}(\%)\end{array}$ & P \\
\hline Gender $^{*}$ & $138(66.3)$ & $71(33.7)$ & \\
Age (years) $^{\dagger}$ & $54.3 \pm 13.5$ & $52.0 \pm 14.3$ & 0.24 \\
Education $^{*}$ & & & \\
$\quad$ Elementary & $75(75.8)$ & $33(69.8)$ & 0.32 \\
$\quad$ Middle & $22(22.2)$ & $15(31.2)$ & \\
$\quad$ Higher & $2(2.0)$ & - & \\
Marital Status & & & \\
$\quad$ No partner & $60(43.8)$ & $13(18.8)$ & \\
$\quad$ With a partner & $56(81.2)$ & $77(56.2)$ & \\
Color* & & & \\
$\quad$ White & $93(67.4)$ & $56(80)$ & \\
$\quad$ Black & $37(26.8)$ & $12(17.1)$ & \\
$\quad$ Other & $8(5.8)$ & $2(2.9)$ & \\
\hline
\end{tabular}

Categorical variables expressed $\mathrm{n}(\%)$; $\uparrow$ Continuous variables expressed as mean \pm standard deviation. Source: prontuário dos pacientes do Ambulatório MULTIHAS.

Table 2 - Risk factors for SAH present in the studied sample $(\mathrm{n}=209)$. Porto Alegre - RS, 2009-2010.

\begin{tabular}{|c|c|c|c|}
\hline Variables & $\begin{array}{c}\text { Male gender } \\
\mathbf{n}(\%)\end{array}$ & $\begin{array}{c}\text { Female gender } \\
\mathrm{n}(\%)\end{array}$ & $\mathbf{P}$ \\
\hline Smoking* & $14(21.2)$ & $26(20)$ & 0.32 \\
\hline Sedentary lifestyle* & $42(66.7)$ & $89(72)$ & 0.45 \\
\hline Alcohol consumption* & $20(35.1)$ & $12(13.2)$ & $0.04+$ \\
\hline $\mathrm{WC}(\mathrm{cm})^{\dagger}$ & $107.6 \pm 14.7^{\S}$ & $102.2 \pm 13^{\S}$ & $0.04+$ \\
\hline BMI $\left(\mathrm{kg} / \mathrm{m}^{2}\right)^{+}$ & $31.5 \pm 6.9$ & $32.7 \pm 7.4$ & 0.31 \\
\hline Total cholesterol $(\mathrm{mg} / \mathrm{dL})^{\dagger}$ & $207.9 \pm 43.4$ & $208 \pm 48.6$ & 0.99 \\
\hline Glucose $(\mathrm{mg} / \mathrm{dL})^{\dagger}$ & $109.9 \pm 39.1$ & $107.6 \pm 43.4$ & 0.82 \\
\hline $\mathrm{SBP}(\mathrm{mmHg})^{+}$ & $170.9 \pm 33.7$ & $164.7 \pm 43.4$ & 0.34 \\
\hline $\mathrm{DBP}(\mathrm{mmHg})^{\dagger}$ & $98 \pm 20.9$ & $96.1 \pm 20,1$ & 0.56 \\
\hline
\end{tabular}

${ }^{*}$ Categorical variables expressed $\mathrm{n}(\%) ;{ }^{\dagger}$ Continuous variables expressed as mean \pm standard deviation; ${ }^{+} \mathrm{p} \leq 0.05 ;{ }^{\S}$ variables above the values recommended by the guidelines.

WC- waist circumference; BMI- body mass index; SBP - systolic blood pressure; DBP - diastolic blood pressure. Source: prontuário dos pacientes do Ambulatório MULTIHAS.

more frequently and underwent treatment for a longer period after diagnosis of SAH compared to men. ${ }^{(14)}$.

Concerning the risk factors studied, sedentary lifestyle was the most significant in the sample: the prevalence was $70.1 \%$. In a cohort study, there was association between low-intensity regular physical activity and a $20 \%$ decrease in mortality ${ }^{(15)}$.

As for lifestyle, the lack of regular exercise deserves special attention, for the patients, besides being physically inactive, had high BP levels. In a systematic review whose objective was to determine 
the impact of physical activity on the mortality of patients with hypertension, the authors demonstrated that patients with high blood pressure, who participated in any amount of physical activity had a reduced risk (16-67\%) of cardiovascular mortality, while in inactive individuals this risk was twice as high ${ }^{(16)}$.

The universal use of $\mathrm{WC}$ and $\mathrm{BMI}$ for $\mathrm{SAH}$ has been questioned by researchers especially in studies involving Asian populations. Many of these studies showed the superiority of the BMI or waist circumference element, frequently with divergent results between genders ${ }^{(17)}$. Another study with 1,454 individuals, for both genders, evaluated the association between anthropometric indices, BMI and WC with SAH. The result demonstrated an association with $\mathrm{SAH}$ for both genders without statistical significance ${ }^{(18)}$, similar to our study whose values obtained for $\mathrm{BP}, \mathrm{WC}$ and $\mathrm{BMI}$ did not differ between genders.

Alcohol consumption was significantly higher among men. However, there was no effect on the increase in BP levels.

Partial results of the Vigitel system about risk factors, regardless of the gender, showed that in the last five years, the prevalence of binge drinking in the overall adult population of 27 cities was almost three times higher in men $(26.2 \%)$ than in women $(9,1 \%)^{(7)}$.

In Poland, unlike the results of this research, one study demonstrated a positive association between individuals who consumed alcoholic beverages and increased BP by $52 \%$. The results of high triglycerides, hyperhomocysteinemia and low HDL- $\mathrm{C}$ were associated in $46 \%, 95 \%$ and $44 \%$ with high alcohol consumption ${ }^{(19)}$.

Thus, chronic diseases, including cardiovascular disorders, are among the priorities of most developing countries where they are the leading causes of mortality and affect the living and health conditions of the population ${ }^{(20)}$.

\section{CONCLUSIONS}

The findings of our study led us to conclude that the risk factors for hypertension had similar prevalence rates between men and women, except for alcohol consumption, higher among men. Not less important, factors such as sedentary lifestyle, obesity and lipid profile, present and proved influ- ential in SAH prevalence, should be considered in healthcare programs.

A limiting aspect of the findings of our study was the prevalence of only $30 \%$ of men in our sample, which demonstrates the need for professionals to encourage this portion of the population to seek primary healthcare services before injuries required specialized care.

Thus, our results confirm the need to adopt nationwide projects such as the Vigitel, which may contribute and participate in the implementation of public policies for prevention and/or promotion of a better quality of life of the Brazilian population.

\section{REFERENCES}

1 Sociedade Brasileira de Cardiologia; Sociedade Brasileira de Hipertensão; Sociedade Brasileira de Nefrologia. VI diretrizes brasileiras de hipertensão. Arq Bras Cardiol. 2010;95(1 Suppl 1):1-51.

2 Williams B. The year in hypertension. J Am Coll Cardiol. 2010;55(1):66-73.

3 Souza FM, Rocha FM, Fernandes FM. Doenças crônicas não-transmissíveis: mortalidade e fatores de risco no Brasil, 1990 a 2006. In: Ministério da Saúde (BR), Secretaria de Vigilância em Saúde. Saúde Brasil 2008: 20 anos do Sistema Único de Saúde (SUS) no Brasil. Brasília (DF); 2009.

4. Santos RP, Horta PM, Souza CS, Santos CA, Oliveira HBS, Almeida LMR, et al. Aconselhamento sobre alimentação e atividade física: prática e adesão de usuários da atenção primária. Rev Gaúcha de Enferm. 2012;33(4):14-21.

5 Felipe GF, Abreu RNDC, Moreira TMM. Aspectos contemplados na consulta de enfermagem ao paciente com hipertensão atendido no Programa Saúde da Família. Rev Esc Enferm USP. 2008;42(4):620-7.

6 Ulbrich EM, Maftum MA, Labronici LM, Montovani MF. Atividades educativas para portadores de doença crônica: subsídio para a enfermagem. Rev Gaúcha de Enferm. 2012;33(2);22-7.

7 Ministério da Saúde (BR), Secretaria de Vigilância em Saúde. Vigitel Brasil 201 1: vigilância de fatores de risco e proteção para doenças crônicas por inquérito telefônico. Brasília (DF); 2012. Série G. Estatística e Informação em Saúde. 
8 Bestehorn K, Wahle K, Kirch W. Stroke risk screening of adults with hypertension: prospective cross-sectional study in primary care. Clin Drug Investig. 2008;28(5):281-9.

9 Mancia G, Fagard R, Narkiewicz K, Redón J, Zanchetti A, Böhm M, et al. $2013 \mathrm{ESH} / \mathrm{ESC}$ guidelines for the management of arterial hypertension: the task force for the management of arterial hypertension of the European Society of Hypertension (ESH) and of the European Society of Cardiology (ESC). J Hypertens. 2013;31(7):1281-357.

10 Xavier HT, Izar MC, Faria Neto JR, Assad MH, Rocha VZ, Sposito AC, et al. V diretrizes brasileiras de dislipidemias e prevenção da aterosclerose. Arq Bras Cardiol. 2013;101(4 Suppl 1):1-22.

11 Ministério da Saúde (BR), Conselho Nacional de Saúde. Resolução nº 196, de 10 de outubro de 1996 [Internet]. Brasília (DF); 1996 [citado 2013 dez 31]. Disponível em: http://conselho.saude.gov.br/ resolucoes/1996/Reso 196.doc.

12 Girotto E, Andrade SM, Cabrera MAS, Ridão EG. Prevalência de fatores de risco para doenças cardiovasculares em hipertensos cadastrados em unidade de saúde da família. Acta Sci Health Sci. 2009;31(1):7782.

13 Ministério da Saúde (BR), Secretaria de Atenção à Saúde, Departamento de Ações Programáticas Estratégicas. Política nacional de atenção integral à saúde do homem: princípios e diretrizes. Brasília (DF); 2008.
14 Rosário TM, Scala LCN, Pereira MRG, Jardim PCBC. Prevalência, controle e tratamento da hipertensão arterial sistêmica em Nobre-MT. Arq Bras Cardiol. 2009;93(6):672-8.

15 Fagard RH. Physical activity, fitness, mortality. J Hypertens. 2012;30(7):1310-2.

16 Rossi A, Dikareva A, Bacon SL, Daskalopoulou SS. The impact of physical activity on mortality in patients with high blood pressure: a systematic review. J Hypertens. 2012;30(7):1277-88.

17 Vikram NK, Pandey RM, Misra A, Sharma R, Devi JR, Khanna N. Non-obese (body mass index $<25$ $\mathrm{kg} / \mathrm{m} 2$ ) Asian Indians with normal waist circumference have high cardiovascular risk. Nutrition. 2003;19(6):503-9.

18 Peixoto MRG, Benício MHA, Latorre MRDO, Jardim PCBV. Circunferência da cintura e índice de massa corporal como preditores da hipertensão arterial. Arq Bras Cardiol. 2006;87(4):462-70.

19 Waśkiewicz A, Sygnowska E. Alcohol intake and cardiovascular risk factor profile in men participating in the WOBASZ study. Kardiol Pol. 2013;71(4):359-65.

20 Cavalheiro AS, Fonseca MJ. Perfil de pacientes atendidos em um ambulatório de HAS: há diferença entre gêneros? [monografia]. Porto Alegre (RS): Programa de Pós-Graduação Lato Sensu Enfermagem em Cardiologia, Instituto de Cardiologia, Fundação Universitária de Cardiologia; 2011.

\author{
Author's address / Endereço do autor / \\ Dirección del autor \\ Silvia Goldmeier \\ Av. Princesa Isabel, 970, $3^{\circ}$ andar, Santana \\ 90620-000, Porto Alegre, RS \\ E-mail: silvia.gold@cardiologia.org.br
}

Received: 09.10.2013

Approved: 11.02.2014 